\title{
THE INTELLIGENCE OF YAKUTS AND ETHNIC RUSSIANS IN YAKUTIA
}

\author{
V.S. SHIBAEV ${ }^{\mathrm{a}}$, R. LYNN
}

${ }^{a}$ Far Eastern Federal University, 8 Sukhanova str., Vladivostok, 690950, Russian Federation

${ }^{b}$ University of Ulster, Coleraine, Northern Ireland, BS52 1SA, United Kingdom

\begin{abstract}
The objective of this paper is to report a study of the intelligence of Yakuts and ethnic Russians in Yakutia. The samples were drawn from Yakutsk, the capital of the Yakutia region containing almost one third of the population of the province, and from Viluysk, a town with the population of approximately 10 600, which is situated $592 \mathrm{~km}$ north-west of Yakutsk. The sample from Yakutsk consisted of 52 ethnic Russian and 128 ethnic Yakut school students with a mean age of 12.0 years attending a typical secondary school. The sample from Viluysk consisted of 7 ethnic Russian and 236 ethnic Yakut school students with a mean age of 12.7 years attending two typical secondary schools. The samples were tested in November 2015 with Raven's Standard Progressive Matrices Plus administered by the first author with a time limit of one hour. The British IQs of the participants were obtained from the norms of the 2008 British standardization. The main results were as follows. First, the British IQ of the Russians averaged from the two samples weighted by sample size was 101.7. However, because both samples were urban the true IQ of Russians in Yakutia is probably about by 3 to 5 IQ points lower. Second, the IQ of the Yakuts was 1.8 IQ points lower than that of the Russians but the difference is not statistically significant $(\mathrm{t}=.76)$. The results therefore indicate that the Yakuts and the Russians in Yakutia have approximately the same IQ.
\end{abstract}

Keywords: SPM+, intelligence, Yakuts, Russia.

\section{Introduction}

The objective of this paper is to report a study of the intelligence of Yakuts and ethnic Russians in Yakutia in Eastern Siberia. Yakutia (also known as Sakha, the former indigenous term) is the largest of the 83 provinces of the Russian Federation. It consists of approximately $3,000,000 \mathrm{~km}^{2}$ but has only a small population given in the 2010 census as approximately 958,500. The capital city is Yakutsk and has a population of approximately 300,000. The next largest cities are Neryungry with a population of approximately 58,000 and Mirny with a population of approximately 34,000 . The population of the province is given in the 2010 census as 64 percent urban. Slightly above 
50 percent of the economy is generated by industrial production consisting primarily of diamond, gold and tin ore mining. The rest of the economy is based largely on agriculture. The GDP per capita of the province is 28th among the provinces of the Russian Federation. The population has all been educated between the ages of 7 and 18 years, which is compulsory for each child in the Russian Federation. The province has a university - the NorthEastern Federal University - in the capital city. Many of the population have internet connection and TV.

The indigenous population are theYakuts, also known as Turkic Sakha. They are classified by Cavalli-Sforza, Menozzi, and Piazza (1996, p. 231) as one of the Arctic peoples most closely related to the Sherpa and Tuva, and more distantly related to the Altaic, Northern Chinese and Uzbeks. They originated in Central Asia and migrated into Yakutia in the 13th and 14th centuries. Russia began to colonise Yakutia in the 17th century and a number of Russians subsequently migrated into the province. The 2010 census gives the population as Yakuts (49.9\%), Russians (37.8\%), Evenks (2.2\%), Ukrainians (2.2\%), Evens (1.6\%) and Tartars $(0.9 \%)$.

The study to be reported is the first of the intelligence of Yakuts and ethnic Russians in Yakutia, but there have been a few studies of the intelligence of ethnic Russians in European Russia and of other ethnic peoples in Eastern Siberia. Grigorenko and Sternberg (2001) have reported a British IQ of 96 for a sample of Russian adults in European Russia tested with the Cattell Culture Fair test and Lynn (2001) has reported a British IQ of 97 for a sample of Russian 14-15 years olds in European Russia tested with the Standard Progressive Matrices. Lynn and Vanhanen (2012, p. 27) give a British IQ of 96.7 for a sample Russian 15 years olds based on PISA results in Math, Science and Language comprehension and a British IQ of 96.6 for all three samples.

Some studies of the intelligence of some of the ethnic minorities in Russia were carried out in the 1920s and 1930s by Luria and others. These have been reviewed by Grigoriev and Lynn (2009) and concluded that the intelligence of these ethnic minorities was lower than that of ethnic Russians. These studies came to an end in 1936 when intelligence testing was banned in the Soviet Union. It was not until the 1960s and early 1970 s that this prohibition was progressively relaxed and research on intelligence in Russia was resumed.

Shibaev and Lynn (2015) have reported a study of the intelligence tested with the Standard Progressive Matrices Plus of a small sample of Evenk/Tungus school children in a village in an isolated rural location in the province of Vladivostok who obtained a British IQ of 80 .

\section{Method}

The samples were drawn from Yakutsk, the capital of the Yakutia region containing almost one third of the population of the province, and from Viluysk, which is situated $592 \mathrm{~km}$ north-west of Yakutsk. Viluysk was officially designated as a city in 2013 but has a population of approximately 10,600 and would be regarded in western countries as a small town. There is no institution of tertiary education but 
there is a museum of local history and a museum of the Yakut's Jew's Harp (the khomus). Most part of the population are connected to the internet.

The sample from Yakutsk consisted of 52 ethnic Russian and 128 ethnic Yakut school students with a mean age of 12.0 years attending a typical secondary school and were all those present in the first year of secondary school on the day of testing. The sample from Viluysk consisted of 7 ethnic Russian and 236 ethnic Yakut school students with a mean age of 12.7 years attending two typical secondary schools and were all those present in the first year of secondary school on the day of testing. There were approximately equal numbers of boys and girls in all the samples. The samples were tested in November 2015 with Raven's Standard Progressive Matrices Plus (Raven, 2008) administered by the first author with a time limit of one hour giving ample time to complete the test.

\section{Results}

The British IQs of the participants were obtained from the norms of the 2008 British standardization given in Raven (2008). The results are shown in Table 1.

\section{Discussion}

There are two points of interest in the results. First, the results given in

Table 1

IQs of Russians and Yakuts in Yakutia

\begin{tabular}{|c|c|c|}
\hline Sample & $\begin{array}{c}\text { Russians } \\
\text { IQ (SD) }\end{array}$ & $\begin{array}{c}\text { Yakuts } \\
\text { IQ (SD) }\end{array}$ \\
\hline Yakutsk & $102.3(17.5)$ & $100.7(14.8)$ \\
\hline Viluysk & $97.1(18.2)$ & $99.5(13.7)$ \\
\hline
\end{tabular}

Table 1 show that the British IQ of the Russians averaged from the two samples weighted by sample size was 101.7. This is a little higher than the British IQ for Russia given as 96.6 on the basis of three studies by Lynn and Vanhanen (2012). However, all the Russians were urban and nearly all lived in the capital city and the urban populations typically obtain higher IQs than rural populations. In a study of intelligence in 79 provinces of the Russian Federation, a correlation of .44 with urbanization has been reported by Grigoriev, Ushakov, Valueva, Zirenko, and Lynn (2016). In the standardization sample of the American WAIS-R, the IQ of the urban sample was 1.9 IQ points higher than that of the rural sample (Reynolds, Chastain, Kaufman, \& McClean, 1987). The populations of capital cities typically obtain higher IQs than the rest of the population, e.g. in the British Isles (Lynn, 1979), France (Lynn, 1980) and Portugal (Almeida, Lemos, \& Lynn, 2011). The IQ of Russians is therefore likely inflated by perhaps 3 to 5 IQ points and the true IQ of the Russians in Yakutia is probably about the same as the 96.6 given by Lynn and Vanhanen (2012). The previous studies of the Russian IQ were based on samples in European Russia. The present results suggest that Russians in Eastern Siberia have approximately the same IQ as those in European Russia.

Second, the results given in Table 1 show that the British IQ of the Yakuts averaged from the two samples weighted by sample size was 99.9 . As with the Russians, this is likely inflated by perhaps 3 to 5 IQ points because the samples were urban and some of them were in the capital city. The IQ of the Yakuts 
was 1.8 IQ points lower than that of the Russians but the difference is not statistically significant $(t=.76)$. The results therefore indicate that the Yakuts and the Russians in Yakutia have approximately the same IQ.

\section{References}

Almeida, L. S., Lemos, G. C., \& Lynn, R. (2011). Regional differences in intelligence and per capita incomes in Portugal. Mankind Quarterly, 52, 213-221.

Cavalli-Sforza, L. L., Menozzi, P., \& Piazza, A. (1996). The history and geography of human genes (Abridged paperback ed.). Princeton, NJ: Princeton University Press.

Grigorenko, E. L., \& Sternberg, R. J. (2001). Analytical, creative and practical intelligence as predictors of self-reported adaptive functioning: a case study in Russia. Intelligence, 29, 57-73.

Grigoriev, A., \& Lynn, R. (2009). Studies of socioeconomic and ethnic differences in intelligence in the former Soviet Union in the early twentieth century. Intelligence, 37, 447-452.

Grigoriev, A., Ushakov, D., Valueva, E., Zirenko, M., \& Lynn, R. (2016). Differences in educational attainment, socio-economic variables and geographical location across 79 provinces of the Russian Federation. Intelligence, 58, 14-17.

Lynn, R. (1979). The social ecology of intelligence in the British Isles. British Journal of Social and Clinical Psychology, 18, 1-12.

Lynn, R. (1980). The social ecology of intelligence in France. British Journal of Social and Clinical Psychology, 19, 325-331.

Lynn, R. (2001). Intelligence in Russia. Mankind Quarterly, 42, 151-154.

Lynn, R., \& Vanhanen, T. (2012). Intelligence: A unifying construct for the social sciences. London: Ulster Institute for Social Research.

Raven, J. (2008). Standard Progressive Matrices-Plus version and Mill Hill Vocabulary Scale Manual. London: Pearson.

Reynolds, C. R., Chastain, R. L., Kaufman, A. S., \& McClean, J. E. (1987). Demographic characteristics and IQ among adults. Journal of School Psychology, 25, 323-342.

Shibaev, V., \& Lynn, R. (2015). The intelligence of the Evenk/Tungus of the Russian Far East. Mankind Quarterly, 55, 202-207.

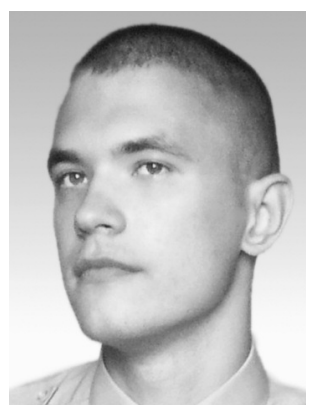

Vladimir S. Shibaev - master of psychology, Far Eastern Federal University.

Research area: intelligence, population psychology, evolutional psychology. E-mail: wladimirdw@gmail.com 


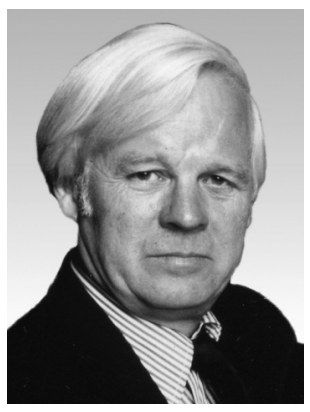

Lynn Richard - emeritus professor, University of Ulster, Ph.D.

Research area: intelligence, sex differences, race differences, eugenics. E-mail: lynnr540@aol.com

\title{
Интеллект якутов и этнических русских в Якутии
}

\author{
В.С. Шибаева ${ }^{\mathrm{a}}$ Р. Линн
}

а Дальневосточный Федеральньй Университет, 690950, Россия, Владивосток, ул. Суханова, д. 8

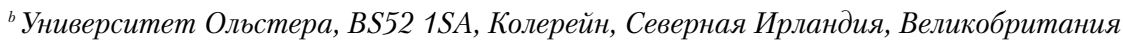

\section{Резюме}

В данной статье сообщается об исследовании интеллекта якутов и этнических русских в Якутии. Тестировались выборки из Якутска, столицы Якутии, в которой проживает почти треть населения региона, и из Вилюйска, города с населением примерно 10600 человек, расположенного в 592 км к северо-западу от Якутска. Выборка из Якутска состояла из 52 этнических русских и 128 этнических якутов, учащихся типичных средних школ. Средний возраст в данной выборке был 12 лет. Выборка из Вилюйска состояла из 7 этнических русских и 236 этнических якутов, учащихся типичных средних школ. Средний возраст в данной выборке был 12.7 года. Выборки тестировались в ноябре 2015 г. с помощью Стандартных прогрессивных матриц плюс Равена. Тестирование проводилось первым автором, с временни́м ограничением в 1 час. IQ респондентов оценивался относительно норм британской стандартизации 2008 г. Основные результаты состояли в следующем. Во-первых, среднее взвешенное значение IQ двух выборок русских относительно британских норм составило 101.7. Однако, так как обе выборки были из городов, действительный IQ русских в Якутии будет, вероятно, примерно на 3-5 баллов IQ ниже этого значения. Во-вторых, IQ якутов был на 1.8 балла IQ ниже, чем у русских, но эта разница незначима $(t=0.76)$. Результаты, таким образом, говорят о том, что якуты и русские в Якутии имеют примерно одинаковый IQ.

Ключевые слова: SPM+, интеллект, якуты, Россия.

Шибаев Владимир Сергеевич - магистр психологии, Дальневосточный федеральный университет.

Сфера научных интересов: интеллект, популяционная психология, эволюционная психология. Контакты: wladimirdw@gmail.com

Линн Ричард -почетный профессор, Университет Ольстера, Ph.D.

Сфера научных интересов: интеллект, половые различия, расовые различия, евгеника.

Контакты: lynnr540@aol.com 